\title{
Tin Monooxide Monolayer as Promising Anode Materials for Recharge Ion Batteries
}

\author{
Aijian Huang, Xiaoli Sun ${ }^{*}$, Sha Dong
}

School of Physical Electronics, University of Electronic Science and Technology of China, Chengdu, 610054, P.R. China

*E-mail: 201511040202@std.uestc.edu.cn

doi: $10.20964 / 2017.11 .08$

Received: 22 July 2017 / Accepted: 28 August 2017 / Published: 12 October 2017

Using density functional theory, $\mathrm{Li}, \mathrm{Na}$ and $\mathrm{Mg}$ adsorption and diffusion on a $\mathrm{SnO}$ monolayer were investigated. The energetically favored adsorption sites and diffusion paths for $\mathrm{Li}, \mathrm{Na}$ and $\mathrm{Mg}$ were determined. The adsorption energies were in the range of $-1.25 \sim-0.94 \mathrm{eV},-0.99 \sim-0.78 \mathrm{eV}$, and -1.11 $\sim-0.66 \mathrm{eV}$ for $\mathrm{Li}, \mathrm{Na}$ and $\mathrm{Mg}$ adsorption with concentrations between $\mathrm{x}=0.03125-1.0$ in $\mathrm{M}_{\mathrm{X}} \mathrm{SnO}$ $(\mathrm{M}=\mathrm{Li}, \mathrm{Na}$, or $\mathrm{Mg}$ ). The volume evolutions were within $-4 \% \sim 8 \%$ after $\mathrm{Li}, \mathrm{Na}$ and $\mathrm{Mg}$ adsorption. The smallest energy barriers were $0.31,0.24$ and $0.21 \mathrm{eV}$ for $\mathrm{Li}, \mathrm{Na}$ and $\mathrm{Mg}$, respectively, diffusing on the $\mathrm{SnO}$ monolayer. The $\mathrm{SnO}$ monolayer showed strong adsorption stability and low $\mathrm{Li}, \mathrm{Na}$ and $\mathrm{Mg}$ diffusion energy barriers with small volume deformations. Therefore, the $\mathrm{SnO}$ monolayer is a promising anode material for rechargeable ion batteries.

Keywords: Monolayer SnO, LIBs, NIBs, MIBs, adsorption energy, diffusion energy

\section{$\underline{\text { FULL TEXT }}$}

(C) 2017 The Authors. Published by ESG (www.electrochemsci.org). This article is an open access article distributed under the terms and conditions of the Creative Commons Attribution license (http://creativecommons.org/licenses/by/4.0/). 